NASA Technical Memorandum 113179

AIAA-98-0711

\title{
Design and Checkout of a High Speed Research Nozzle Evaluation Rig
}

Raymond S. Castner and John D. Wolter Lewis Research Center, Cleveland, Ohio

Prepared for the 36th Aerospace Sciences Meeting and Exhibit sponsored by the American Institute of Aeronautics and Astronautics Reno, Nevada, January 12-15, 1998

National Aeronautics and Space Administration

Lewis Research Center 
This report is a preprint of a paper to be presented at a professional meeting.

Available from

NASA Center for Aerospace Information

800 Elkridge Landing Road

Linthicum Heights, MD 21090-2934

Price Code: A03
National Technical Information Service 5287 Port Royal Road Springfield, VA 22100

Price Code: A03 


\title{
DESIGN AND CHECKOUT OF A HIGH SPEED RESEARCH NOZZLE EVALUATION RIG
}

\author{
Raymond S. Castner and John D. Wolter \\ National Aeronautics and Space Administration \\ Lewis Research Center \\ Cleveland, Ohio 44135
}

\begin{abstract}
The High Flow Jet Exit Rig (HFJER) was designed to provide simulated mixed flow turbojet engine exhaust for one-seventh scale models of advanced High Speed Research test nozzles. The new rig was designed to be used at NASA Lewis Research Center in the Nozzle Acoustic Test Rig and the $8 \times 6$ Supersonic Wind Tunnel. Capabilities were also designed to collect nozzle thrust measurement, aerodynamic measurements, and acoustic measurements when installed at the Nozzle Acoustic Test Rig. Simulated engine exhaust can be supplied from a high pressure air source at $33 \mathrm{lb}$ of air $/ \mathrm{sec}$ at $530^{\circ} \mathrm{R}$ and nozzle pressure ratios of 4.0. In addition, a combustion unit was designed from a $J-58$ aircraft engine burner to provide $20 \mathrm{lb}$ of air $/ \mathrm{sec}$ at $2000^{\circ} \mathrm{R}$, also at nozzle pressure ratios of 4.0. These airflow capacities were designed to test High Speed Research nozzles with exhaust areas from 18 to 22 in. $^{2}$. Nozzle inlet flow measurement is available through pressure and temperature sensors installed in the rig. Research instrumentation on High Speed Research nozzles is available with a maximum of 200 individual pressure and 100 individual temperature measurements. Checkout testing was performed in May 1997 with a 22 in. ${ }^{2}$ ASME long radius flow nozzle. Checkout test results will be summarized and compared to the stated design goals.
\end{abstract}

\section{Introduction}

A new ground test rig has been designed at the NASA Lewis Research Center in Cleveland Ohio to support NASA's High Speed Research Program. This new rig is the result of a $\$ 1.6$ million effort to design a nozzle evaluation test rig called the High Flow Jet Exit Rig (HFJER). The HFJER will be used in both a low speed acoustic free-jet facility called the Nozzle Acoustic Test Rig, and in the $8 \times 6$ Supersonic Wind Tunnel. Both facilities are located at the NASA Lewis Research Center.
The HFJER is designed to provide simulated mixed flow turbojet engine exhaust for $1 / 7$ scale models of advanced High Speed Research test nozzles. Capabilities were also designed to collect nozzle thrust measurement, aerodynamic measurements, and acoustic measurements when installed at the Nozzle Acoustic Test Rig. Simulated engine exhaust can be supplied from a high pressure air source at $33 \mathrm{lb}$ of air/sec at $530^{\circ} \mathrm{R}$ and nozzle pressure ratios of 4.0. In addition, a combustion unit was designed from a J-58 burner to provide $20 \mathrm{lb}$ of air $/ \mathrm{sec}$ at $2000^{\circ} \mathrm{R}$, also at nozzle pressure ratios of 4.0. These airflow capacities were designed to test High Speed Research nozzles with exhaust areas from 18 to 22 in. $^{2}$. Nozzle inlet flow measurement is available through pressure and temperature sensors installed in the rig. Research instrumentation on High Speed Research nozzles is available with a maximum of 200 individual pressure and 100 individual temperature measurements.

The HFJER rig configuration was designed to support High Speed Research nozzles on a strut and sting in the Nozzle Acoustic Test Rig free jet and in the $8 \times 6$ Supersonic Wind tunnel. In addition to the strut/sting arrangement, the HFJER consists of a high temperature air supply system and a thrust measurement system. Design life of the High Flow Jet Exit Rig was $10000 \mathrm{hr}$ at $2000^{\circ} \mathrm{R}$. To meet this goal, all high temperature components of the rig are designed and fabricated from hastelloy-X. The design meets ASME boiler and pressure vessel code to ensure a long service life. The thrust measurement system was designed to handle $2000 \mathrm{lb}$ of nozzle thrust maximum, with a measurement accuracy of 0.1 percent full scale. The flow system was designed to measure flow to 0.5 percent full flow. Checkout testing was performed in May 1997 with a 22 in. ${ }^{2}$ ASME long radius flow nozzle. Checkout test results will be summarized and compared to the stated design goals. 


\section{Design Requirements}

The High Flow Jet Exit Rig was designed to support testing of scale model exhaust nozzles in the NASA Lewis $8 \times 6$ Supersonic Wind Tunnel*(8×6 SWT) and in the NASA Lewis Nozzle Acoustic Test Rig ${ }^{\dagger}$ (NATR). The $1 / 7$ scale exhaust nozzles possess exhaust areas between 18 and 22 in. $^{2}$. To simulate actual nozzle operation, the HFJER had to be capable of delivering $20 \mathrm{lb} / \mathrm{sec}$ of airflow at $2000^{\circ} \mathrm{R}$. This flow rate provides a maximum of $60 \mathrm{psia}$ of air pressure upstream of a 22 in. $^{2}$ test nozzle. In addition, the rig was designed for ambient flow conditions $\left(530^{\circ} R\right)$ of $33 \mathrm{lb} / \mathrm{sec}$ of airflow. This flow rate provides a maximum of 100 psia air pressure. To determine exhaust nozzle performance, these airflow rates had to be measured within 0.5 percent of full flow. In addition to airflow measurement, the measurement of nozzle thrust levels was desired. To meet this requirement, a $2000 \mathrm{lb}$ thrust measurement system was designed with a static accuracy of 0.1 percent full scale. The thrust measurement system was required to switch load ranges of 0 to $1000 \mathrm{lb}$ and 0 to $500 \mathrm{lb}$.

To perform supersonic testing in the $8 \times 6 \mathrm{SWT}$, the HFJER could not block more than one percent of the wind tunnel test section area. This confined the rig to 9.0 in. in diameter at the test nozzle. The allowed area blockage was increased upstream of the test nozzle, where the rig was confined to a 13 in. diameter with a support strut no more than 3.25 in. thick. The $8 \times 6$ SWT size restricted the maximum length of the HFJER; allowing test nozzles to be no longer than 72 in. long. The maximum feasible design weight was chosen as $100 \mathrm{lb} / \mathrm{ft}$ of length. As a result, test nozzles are limited to $600 \mathrm{lb}$ total weight without additional support. The $8 \times 6$ SWT imposed the toughest criteria for the design of the HFJER. The restrictions were not required for the NATR, but the same rig design was adapted to fit the NATR so one rig could support testing in a cost effective manner.

A ten year service life was chosen for the HFJER. In this manner, the rig would support many future test programs in an aerospace research environment where budgets shrink each year. To achieve a ten year service life, past test results were examined to determine the maximum number of test hours expected each year. Testing at NATR and the $8 \times 6$ SWT can add up $1000 \mathrm{hr}$ in a year. As a result, the HFJER was designed to meet a 10000 design life. To meet this life requirement, the design team chose to follow ASME Boiler and Pressure Vessel Code Section VIII Divison 1 guidelines. Pressure Vessel code

\footnotetext{
*Soeder, R.H., "NASA Lewis 8- By 6-Foot Supersonic Wind Tunnel User Manual," NASA TM-105771, February 1993

†Castner, R.S., "The Nozzle Acoustic Test Rig; An Acoustic and Aerodynarnic Free-Jet Facility," AIAA-94-2565, June 1994
}

does not rate materials above $1500^{\circ} \mathrm{F}$. Alternate sources were chosen to obtain material properties at $1540^{\circ} \mathrm{F}$ without significantly compromising the use of Pressure Vessel Code guidelines.

Calibration nozzles were required to verify proper operation of the High Flow Jet Exit Rig. Three nozzles were built: (1) 18 in. $^{2}$ ASME contoured calibration nozzle, (2) 22 in. $^{2}$ ASME contoured calibration nozzle, and (3) 18 in. $^{2}$ round convergent nozzle. The ASME flow nozzles ${ }^{\ddagger}$ are used in the industry as standard thrust and flow calibration nozzles, and the round convergent nozzle is used as an acoustic reference.

\section{Design Concepts}

Three design concepts were examined to provide a test rig to meet the desired requirements. The first concept was similar to the original NASA Lewis Jet Exit $\mathrm{Rig}^{\dagger}$ shown in Fig. 1. The conceptual rig was defined as a mixed flow transition section based on the two high pressure air flows housed in the existing Jet Exit Rig strut. In this concept the strut supported an in-line arrangement of a new flow mixing section, a new thrust measurement system, a new combustion system, and new flow measurement station.

The second concept was a variation on the first, with two flows mixed downstream of the combustion section. This would allow constant air flow through the combustion section. Hot and cold air flows would be mixed to provide the desired pressure and temperature.

The third design concept would not use any existing components from the old Jet Exit Rig. A new nozzle support strut and stinger would be designed with the required air supply capabilities. This new design concept placed a combustion section, based on an aircraft engine burner, outside the wind tunnel. The thrust balance was also placed outside the tunnel.

The design process identified advantages and disadvantages for each concept. The third concept was chosen as the concept which best met the set requirements. This concept was named the High Flow Jet Exit Rig, see Fig. 2, and was believed to be more reliable than the first concepts. Reliability was evaluated based on the technical risk associated with the design of the combustor section and the thrust balance section. By removing these from an in-line configuration, NASA Lewis engineers were able

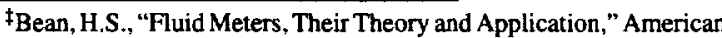
Society of Mechanical Engineers, 6th ed, 1971.
} 


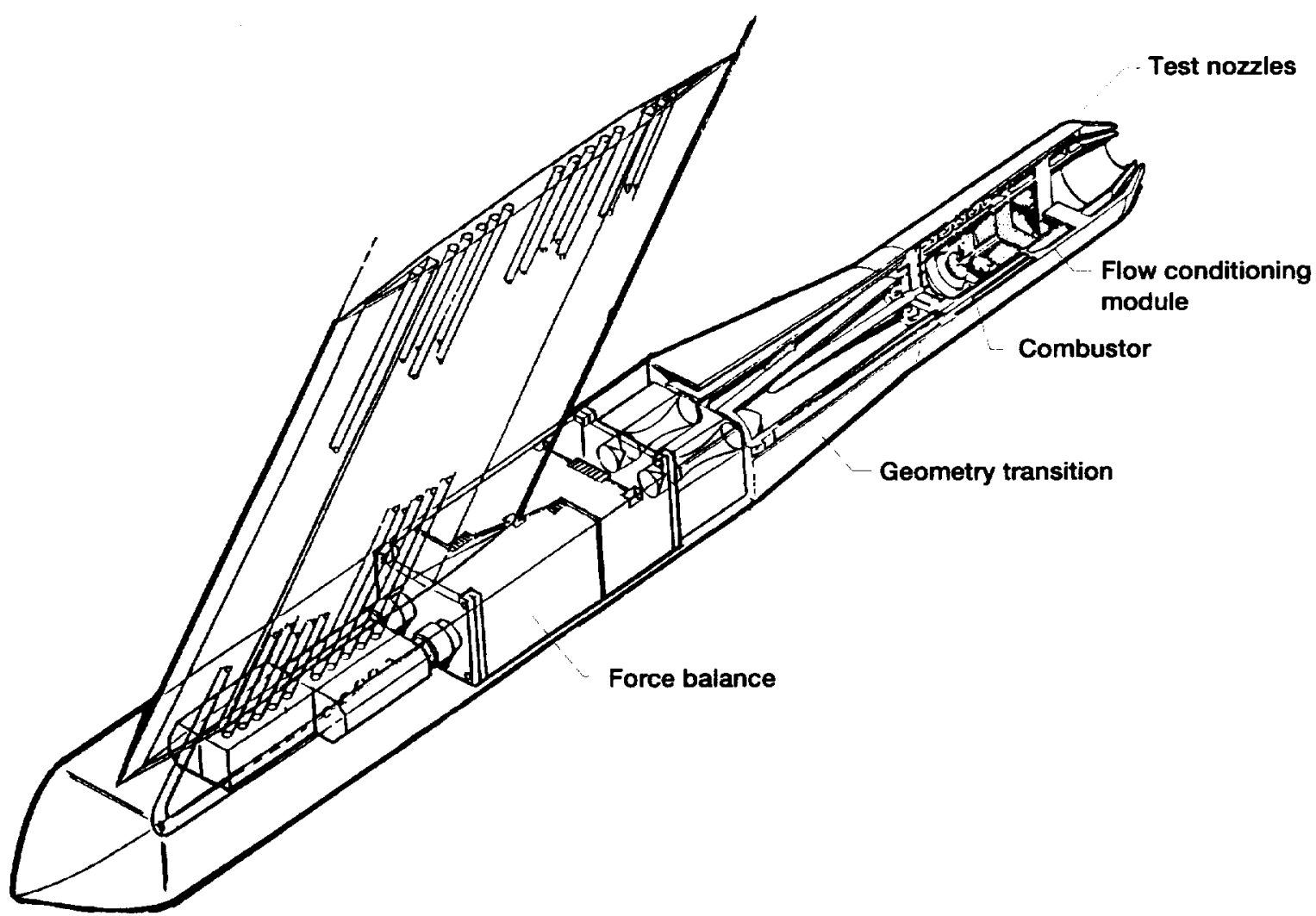

Figure 1.-Jet exit rig.

to design systems with which they were familiar and could rely on past experience. A number of technical challenges were eliminated by separating the thrust measurement balance from the hot gas stream, and by using available technology for the combustion section.

\section{Rig Description}

The High Flow Jet Exit Rig (HFJER) is shown in Fig. 3 as installed in the Nozzle Acoustic Test Rig (NATR). Figure 2 shows a more detailed view of the rig on a support platform as designed to fit in the NATR. Future installations in the $8 \times 6 \mathrm{SWT}$ will invert the assembly so it hangs from a ceiling support.

Figure 2 indicates the location of the "combustor," which heats 450 psig compressed air before it is delivered to the HFJER. The combustor is designed around a J-58 aircraft engine burner. This burner was selected due to its stable operating characteristics over a wide range of pressures and flow rates. NASA Lewis design engineers have experience with the $\mathrm{J}-58$ burner in facilities such as

\footnotetext{
\$Perusek, G.P., "Powered lift facility at NASA Lewis Research Center's Aeroacoustic Propulsion Laboratory," NASA-TM-106577, Jun 01, 1994
}

the Powered Lift Rig, $\$$ and the Advanced Subsonic Combustion Rig. The 450 psig combustion air enters a 20 in. diameter carbon steel plenum through an 6 in. diameter pipe from the right side (aft looking forward). The $\mathrm{J}-58$ combustor is housed in a 16 in. diameter pipe concentrically located inside the plenum. The inlet to the combustor from the annular plenum has a $1 / 8 \mathrm{in}$. thick honeycomb flow straightener. The J-58 combustor is taken directly from a J-58 aircraft engine. It has 6 air assisted fuel spray nozzles which supply the atomized fuel. Fuel is supplied at $650 \mathrm{psig}$, and ignition of the mixture is achieved with the J-58 aircraft ignitor.

The J-58 burner exhausts into the lower air manifold assembly, also shown in Fig. 2. The lower air manifold assembly consists of a pipe tee, a left side and a right side manifold. The pipe tee is an insulated shell design. The body of the tee is a 16 in. diameter carbon steel pipe shell, with two 10 in. diameter off-takes. Internally, the flow diameter expands from the 11.5 in. diameter combustor exhaust to a 12.25 in. inner sleeve flow diameter, creating an air plenum downstream of the J-58 combustor. The end 


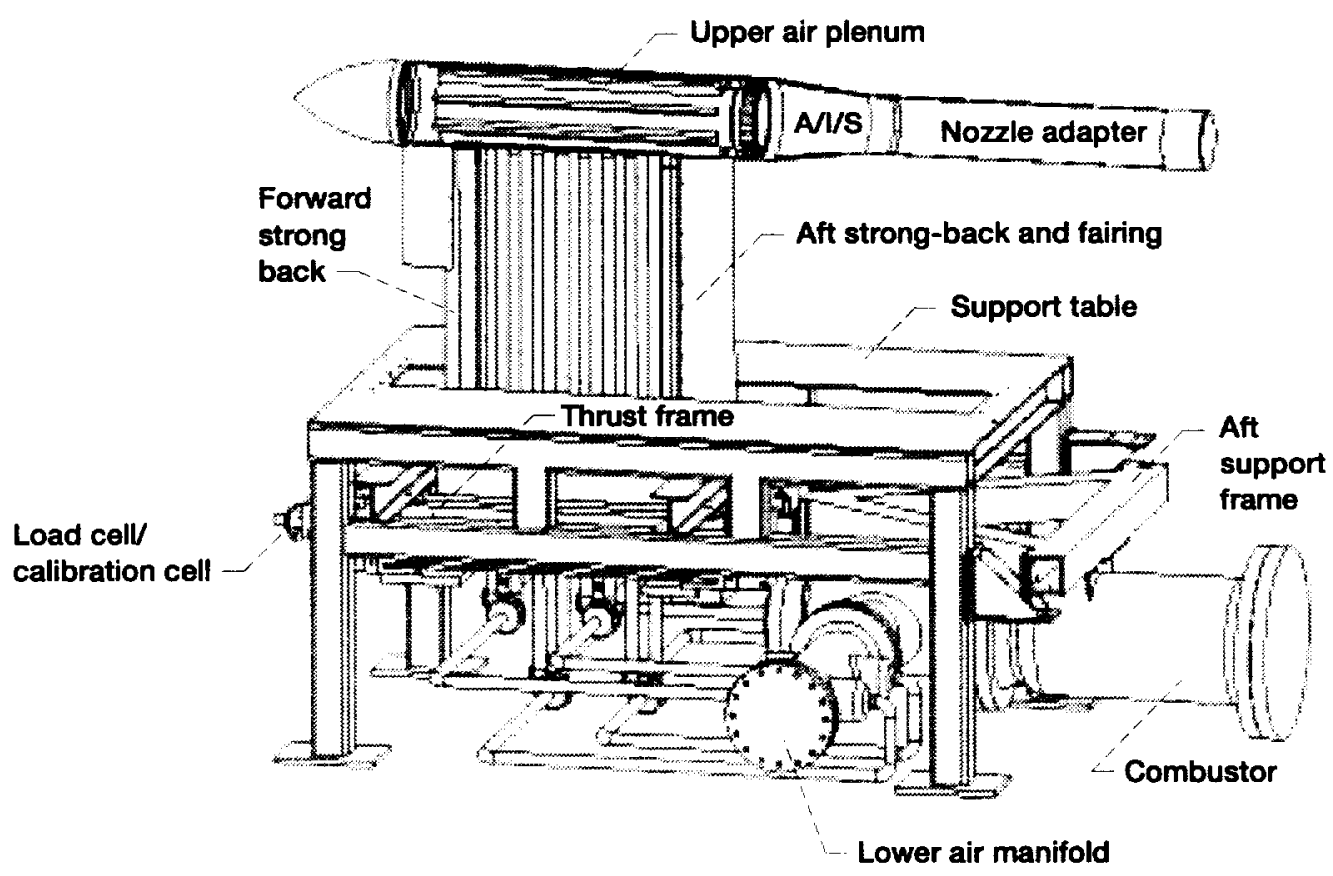

Figure 2.-High flow jet exit rig.

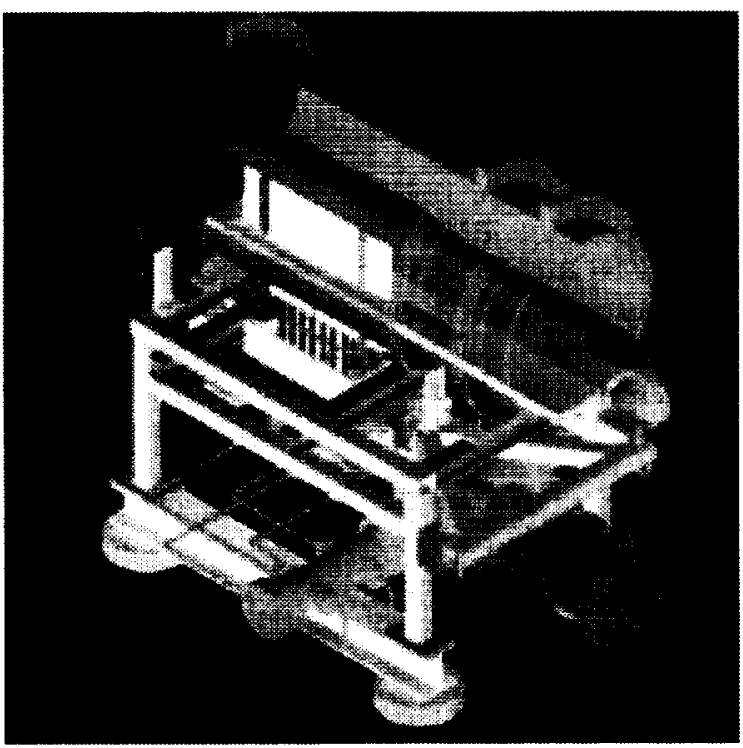

Figure 3.- HFJER at NATR.

of the plenum has a vertical flow splitting wedge, see Fig. 4. Left and right off-takes are provided with two eight inch conical sleeves. Each sleeve reduces to 4.5 in. diameter. The inner sleeves are constructed of 309 stainless steel. The sleeves are centered in the tee and insulated with a cast silicon carbide ceramic, reducing heat transfer to the carbon steel shell. Water cooling on the steel shell is provided by multiple wraps of $0.5 \mathrm{in}$. diameter stainless

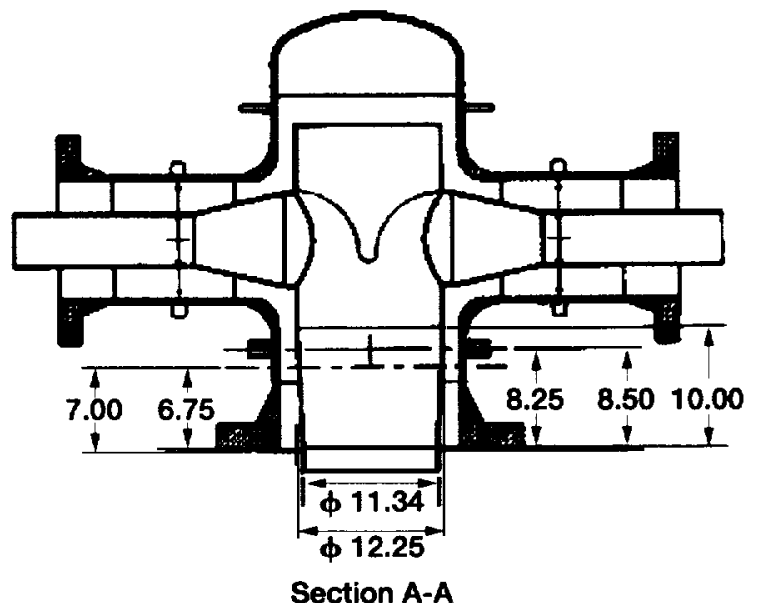

Figure 4.-HFJER lower manifold toe.

steel tubing. $8 \mathrm{gal} / \mathrm{min}$ of water provide cooling to protect thrust balance components from heat radiated by the tee.

The tee section exhausts heated air to both the left and right side manifolds. These manifolds are also carbon steel shells, constructed of $10 \mathrm{in}$. diameter pipe. The shells contain a $4.5 \mathrm{in}$. flow sleeve, fabricated from 309 stainless steel perforated sheet. The sheet has $1 / 8$ in. perforations and 40 percent open area. The outer layer of the sheet is overlaid with 20 mesh 28 gage inconel 601 wire cloth. These sleeves are also centered in the pipe with a bulk 
refractory ceramic fiber insulation. The insulation reduces heat transfer to the outer carbon steel shell. The perforated metal assembly combined with the fibrous insulation also provides an acoustic muffler design; to reduce the level of flow noise created from the combustion process. The carbon steel pressure shells on both right and left side are water cooled with multiple wraps of 0.5 in. diameter stainless steel tubing. Eight $\mathrm{gal} / \mathrm{min}$ of water provide cooling to reduce the amount of heat radiated to the thrust balance system.

Both the right and left manifolds exhaust into 41 -in. diameter hastelloy-X pipes, providing a total of eight high temperature air supply pipes. These pipes are welded to the 10 in. manifolds to 6 in. schedule 40 pipe caps. Internally, the perforated metal liner consists of 1 in. diameter off-takes which provide a slip-fit to supply air into the hastelloy pipes. Externally the hastelloy piping is insulated with a ceramic fiber blanket insulation to prevent excessive heat loss and to reduce heat radiated to the thrust system. The end of each supply pipe is terminated with a 1 in. hub and clamp assembly, which takes the place of a pipe flange.

The hubs attach to eight vertical hastelloy-x pipes, supplying airflow through a support strut to an upper air plenum. The upper air plenum is a hastelloy- $x$ forging and provides the basis for the air supply system and support structure for test nozzles to be mounted on the HFJER. The eight supply tubes are housed in a strut assembly which is composed of a forward and an aft strong-back support. The strong-back supports are bolted to the live side of the thrust frame, to be described later. The aft strong-back is bolted to the plenum. The forward strong-back is pinned to the plenum to provide vertical support only, lateral support is a slip fit to provide thermal growth at elevated temperatures of the plenum. The entire strut and upper air plenum assembly is housed in a 304 stainless steel fairing to provide an aerodynamic profile when installed in the NATR or the $8 \times 6$ SWT. Leading and trailing edge fairings on the strut are $a 20^{\circ}$ included angle. The nose-cone is an ogive contour specified for $8 \times 6$ SWT operation at supersonic speeds.

The downstream end of the upper air plenum was machined to house up to three pressure reducing plates, or "choke plates." These plates are 1.125 in. thick and 8 in. in diameter. The plates were sized to maintain high air pressures through the 81 -in. diameter supply pipes at the desired flow rates, and to reduce the air to useful pressures for scale aircraft exhaust nozzle testing. For 18 to 22 in. $^{2}$ exhaust nozzles, only two plates were fabricated. The first has 396 holes of 0.135 in. diameter. The second has 394 holes of $0.212 \mathrm{in}$. diameter. The plates are separated by a $3.2 \mathrm{in}$. thick spacer ring. These plates back pressure the system to allow $20 \mathrm{lb} / \mathrm{sec}$ of airflow at $2000^{\circ} \mathrm{R}$, as well as $33 \mathrm{lb} / \mathrm{sec}$ of airflow at ambient air temperature.

The downstream end of the upper air plenum was also formed to create the mating flange for the "Acoustic/ Instrumentation/Seed" section, or $\mathrm{A} / \mathrm{I} / \mathrm{S}$. This section is also machined from a hastelloy- $x$ forging. The $A / / / S$ section houses a short $7 \mathrm{in}$. long muffler assembly which matches the inner flow diameter of 7 in. The acoustic muffler is fabricated from a sheet of rolled 304 stainless steel hexagonal honeycomb with a $3 / 8$ in. cell size. The 0.5 in. thick honeycomb is welded to a 0.024 thick perforated metal sheet which forms the inner flow surface. The perforations are 0.050 in. holes on 0.082 in. staggered centers, creating 34 percent open area. Behind the perforated metal, each honeycomb cell is packed with 10 layers of glass fiber matting. Four flow measurement rakes are installed downstream of the muffler. These rakes consist of 11 total temperature probes and 10 total pressure probes. Instrumentation will be described in detail in a later section. A spray bar for particle injection is installed downstream of the instrumentation rakes. The HFJER provides one spray bar for the injection of particles to be used as a seed for Laser Doppler Velocimetry or Particle Image Velocimetry. The spray bar is a $3 / 8$ in. thick 24 percent NACA airfoil. The airfoil span is $7 \mathrm{in}$. long with 28 openings. With fourteen openings on a side, each 0.064 in. diameter opening has a $45^{\circ}$ downstream spray angle. During operation, an atomized mixture of water and one micron diameter silicon dioxide particles is supplied to the spray bar. The water evaporates when it encounters hot gas, leaving the one micron particles to seed the flow.

The downstream flange of the A/I/S section was designed with a 7.0 in. diameter flow area. The external diameter reduces throughout the $\mathrm{A} / \mathrm{L} / \mathrm{S}$ section from a 13.0 to a $9.0 \mathrm{in}$. external diameter. The external diameter meets the 1 percent wind tunnel area blockage requirement for test models in the $8 \times 6 \mathrm{SWT}$. This flange is intended for mounting of scale aircraft exhaust nozzle concepts. Also, a number of calibration nozzles can be installed at this location. To match the anticipated length of a research exhaust nozzle, a 51 in. long nozzle adapter was designed. Using the adapter, a number of calibration nozzles can be utilized: (1) an 18 in. ${ }^{2}$ ASME contour thrust calibration nozzle, (2) a 22 in. $^{2}$ ASME calibration nozzle, and (3) an 18 in. $^{2}$ round convergent acoustic calibration nozzle.

The strut, the upper air plenum, the lower air manifold assembly, and the combustor are all live elements in the thrust measurement system. The system consists of a thrust measurement frame and an aft support frame. The lower air manifold and the combustor are supported by the aft support frame. The aft support frame is in direct contact 
with the thrust measurement frame at one point, and is capable of transmitting axial loading only to the thrust measurement frame. The strut and upper air plenum are directly mounted to the thrust measurement frame.

The thrust measurement frame consists of two rectangular steel frames which are connected at four corners by load bearing flexures. These flexures are fabricated from stainless steel and are designed to allow displacement only in the axial direction. They restrain HFJER loads in all other axes. The axial direction is restrained by a load measurement cell, which is installed in a fixture connecting the live and ground frame. The HFJER strut assembly passes through both frames and is directly bolted to the lower frame, while the upper frame is bolted to the HFJER support table. The load measurement cell was designed to measure axial loads up to $2000 \mathrm{lb}$. A calibration system was installed in parallel with the measurement system. The calibration system consists of a calibration load cell and a stepper motor. The motor actuates the calibration cell to apply and measure an input load. The input load is compared with the output load of the thrust measurement system, creating a system calibration.

\section{Fluid Systems}

Three fluid systems are required to operate the High Flow Jet Exit Rig. A cooling water system, a high pressure air system, and a high pressure jet fuel system. The cooling water system requires an operating pressure of $120 \mathrm{psig}$ and $80 \mathrm{gal} / \mathrm{min}$. The existing system at the Nozzle Acoustic Test Rig is a closed system which uses a 50 percent water and 50 percent ethylene glycol mixture. The mixture allows system operation in a semi-outdoor environment during cold weather. This systems consists of a $750 \mathrm{gal}$ reservoir and a 120 psig water pump. To keep the ethylene glycol system temperature below $120^{\circ} \mathrm{F}$, a heat exchanger is used to transfer excess heat from the ethylene glycol to water supplied by the NASA Lewis cooling tower system.

High pressure air is supplied by the centralized $450 \mathrm{psig}$ combustion air services at NASA Lewis Research Center. The HFJER requires at least 450 psig with a maximum flow rate of $33 \mathrm{lb}$ of air/sec. The air is supplied to the HFJER through an eight inch stainless steel piping system which consists of flow measurement and flow control. Flow measurement is provided by a 6 in. diameter unchoked venturi with a throat diameter of $2.60 \mathrm{in}$. Flow rate is controlled by a four inch butterfly $v$-port ball valve. Controls are provided for remote operation.

The high pressure jet fuel system requires $6 \mathrm{gal} / \mathrm{min}$ of Jet-A or JP-5/JP-8 fuel at a pressure of $650 \mathrm{psig}$. Flow control is provided by a remote operated globe valve, and is measured with a propeller style flow-meter. The ignition sequence requires cooling water and $10 \mathrm{lb} / \mathrm{sec}$ of air flow. An electrical aircraft ignitor is energized and fuel flow is switched on through a shutoff valve to supply the J-58 combustor. Thermocouples downstream of the J-58 are used during the ignition sequence to stop the flow of fuel if operation temperature is not achieved in $10 \mathrm{sec}$. This prevents buildup of excess fuel which may cause damage to the burner or HFJER rig components. Air flow is maintained to purge unburned fuel in the event of a failed ignition or a combustor flame-out.

\section{Instrumentation}

Instrumentation for the High Flow Jet Exit Rig is shown in Fig. 5. The high pressure combustion air flow is metered through the venturi flow-meter previously described. The instrumentation used for this air metering is shown in Fig. 5 at stations $U, V$ and $W$. The instrumentation consists of three upstream static pressure measurements, three differential pressure measurements across the upstream and throat areas, and three downstream temperature measurements. To maintain measurement accuracy, three ranges of pressures are measured between the venturi inlet and the venturi throat: 10,25 , and 50 psid. An automated system of valves selects the proper range during operation. This system is designed to accommodate the desired 0.5 percent accuracy for flow measurement.

Downstream of the J-58 combustor are two temperature rakes located at station 2 . This station is used to determine the temperature uniformity exiting the combustor section. The instrumentation consists of two rods oriented perpendicular to the flow and at $90^{\circ}$ to each other. Each sensor rod has six thermocouples mounted on the surface. This configuration was chosen for simple installation through two 0.75 in. diameter threaded pipe taps which penetrate the wall of the lower manifold tee.

Downstream of the rakes are stations 3 and $3 \mathrm{a}$, which are located after the flow has turned through the lower manifold tee. These two stations measure gas temperature and pressure in the lower manifold and are duplicated in both the left and right side lower manifolds. The thermocouple sensors which span the flow at station $3 \mathrm{a}$ are similar to station 2 in construction. They are used to detect non uniform temperature profiles and to detect flow problems in the lower manifold.

Stations 4, 5 and 6 are designed to measure static pressure upstream and downstream of each "choke-plate" described previously. In this manner, the pressure drop across each plate can be evaluated. Station 7 is used to 
(Not to scale; some details simplified or omitted)

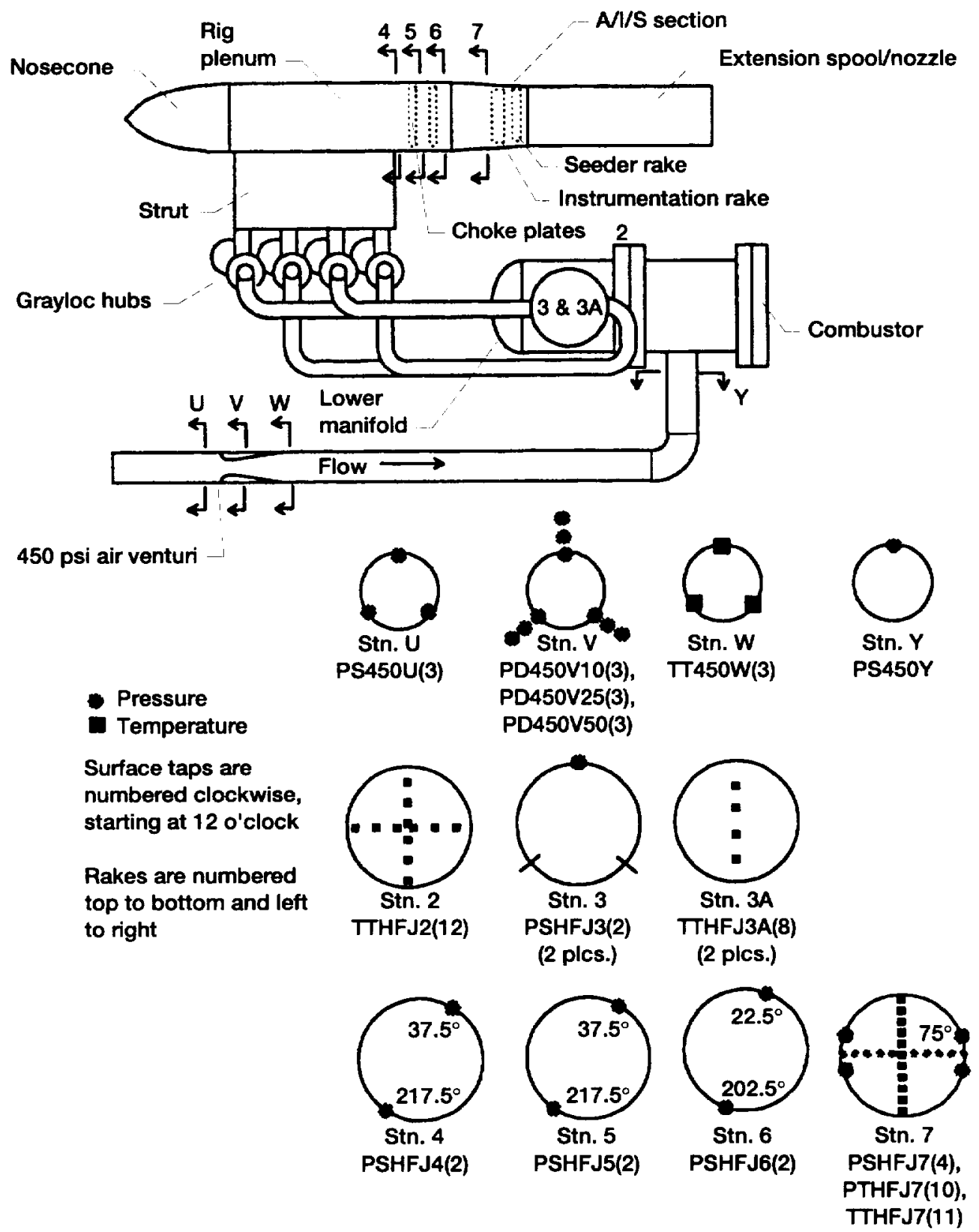

Figure 5.-Instrumentation schematic for high flow jet exit rig. 
measure total pressure, total temperature and static pressure. These measurements span the flow, with probes located on five equal flow areas. One additional temperature measurement is located at the center. The measurements are combined to calculate the inlet conditions to a test nozzle; the most important conditions are nozzle pressure ratio and nozzle inlet total temperature.

In addition to the diagnostic instrumentation described here, the HFJER was designed to accommodate up to 200 pressure and 100 temperature measurements for use on research nozzles. Research nozzles are mounted downstream of station 7 . The pressure tubing and thermocouple wiring to support these aerodynamic performance measurements are housed under the HFJER cover plates.

\section{Results}

Some results have been obtained for the actual performance of the HFJER and compared to the design requirements. These results are from a "check-out" test which was done at NASA Lewis Propulsion Systems Laboratory-Side Four (PSL-4). The check-out testing utilized all support systems needed to operate the HFJER. The schedule for this testing allowed data acquisition from April 25 to May 21, 1997. In this time period five thrust calibrations were performed, four cold flow test runs and three hot flow test runs.

In addition to the maximum flow rate and temperature, two important goals were (1) to assess thrust balance operability and (2) to assess both cold and hot flow operation of the HFJER. Two sets of thrust calibration data are presented in Figs. 6 and 7. The data from Fig. 6 was the first thrust balance data collected in late April and early May 1997. The figure shows the HFJER thrust balance

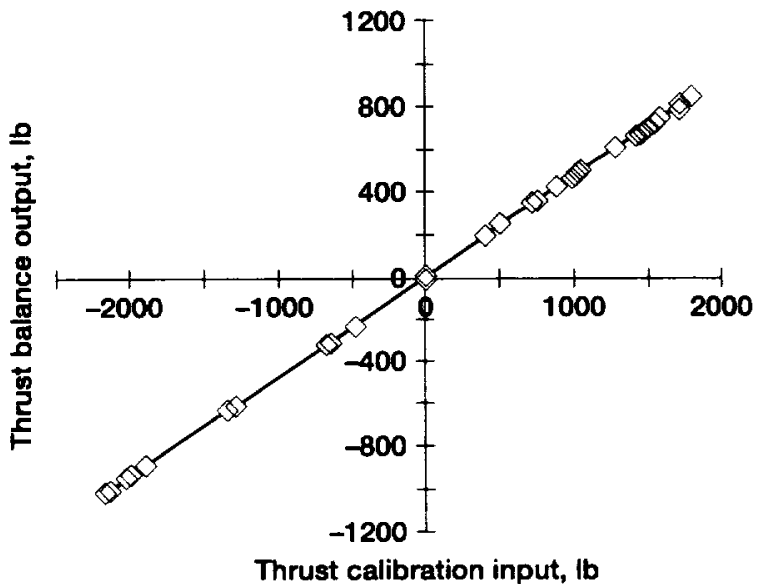

Figure 6.-HFJER thrust balance static calibration with original rear flexures. load cell output as a function of the thrust calibration load cell input, previously described. A problem was noticed immediately; the output of the thrust balance was only 44 percent of the calibration input. A study was performed to locate where the remaining calibration load was absorbed by the thrust measurement system. Deflections resulting from the calibration input were studied at various locations around the thrust system. Based on results, it was determined the aft load bearing flexures on the aft support frame did not provide proper frame deflections in the axial direction. As a result, the full calibration load was not transmitted to the HFJER measurement load cell. These aft support frame flexures were redesigned and fabricated between May 5 and 16, 1997. The redesigned flexures were installed for testing on May 19,1997. The output from a thrust calibration with the new flexures is shown on Fig. 7. Figure 7 results show the HFJER thrust balance output as 89 percent of the thrust calibration input; an improvement from the previous 44 percent.

During the fabrication period for the redesigned aft support frame flexures, both cold and hot flow operation of the HFJER was investigated. One cold flow test was performed on May 6, 1997; which was followed by two hot flow tests on May 8 and 9, 1997. Results from testing indicated the desired maximum air flow rates could be achieved at $33 \mathrm{lb}$ of air $/ \mathrm{sec}$ and $530^{\circ} \mathrm{R}$; and at $20 \mathrm{lb} / \mathrm{sec}$ and $1750^{\circ} \mathrm{R}$. A maximum temperature of $1750^{\circ}$ was chosen instead of the maximum design point of $2000^{\circ} \mathrm{R}$. This change reflects the reduced temperature requirements of planned testing. The rig was tested at conditions around the operating envelope given in Fig. 8. The figure indicates the nozzle pressure ratios achieved (with respect to atmospheric pressure) at a variety of air exhaust temperatures. All conditions within the enclosed boundaries of Fig. 8 are possible.

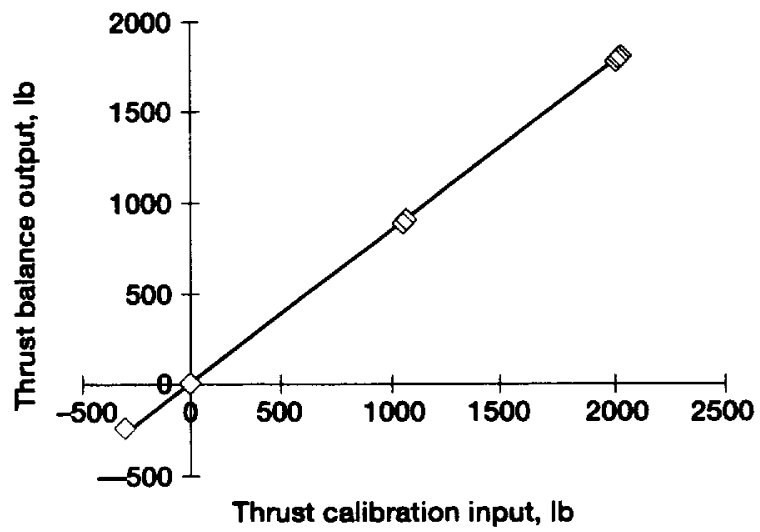

Figure 7.-HFJER thrust balance static calibration with new rear flexures. 


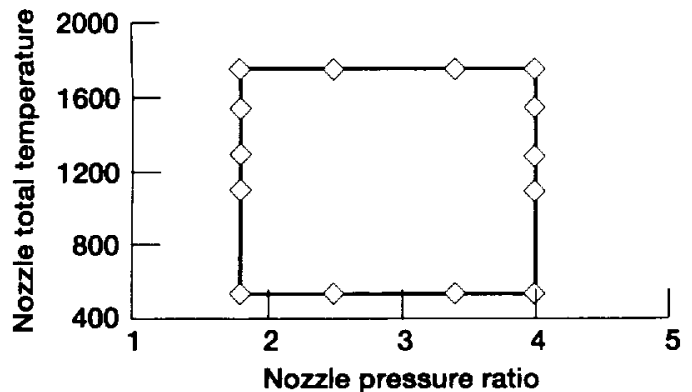

Figure 8.- High flow jet exit rig operating envelope.

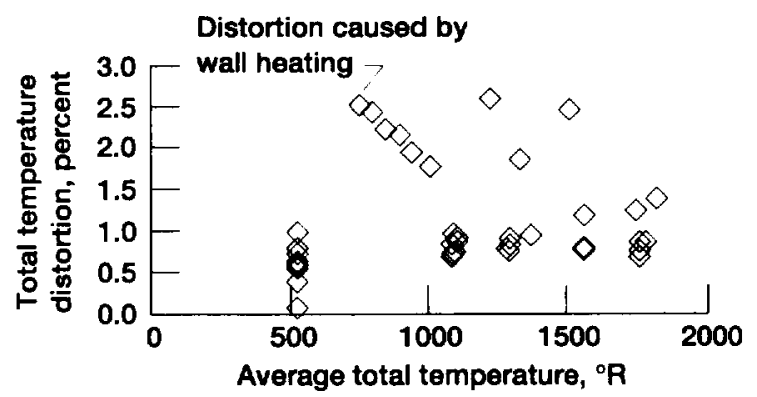

Figure 9.-HFJER total temperature distortion levels.

Actual test conditions in PSL-4 varied from plans to exhaust at standard atmospheric pressure. To maintain proper airflow through the PSL-4 facility, the PSL-4 altitude chamber was closed and the chamber was evacuated to 8 psia. All HFJER flow data was collected at 8 psia atmospheric pressure. Airflow results were collected with the 22 in. $^{2}$ ASME calibration nozzle. The ASME nozzle inlet conditions are measured at station 7, as previously shown in Fig. 5. In addition to maximum air flow and maximum temperature, the measured distortions of nozzle inlet temperature and pressure were collected.

Figure 9 shows the level of nozzle inlet temperature distortion for all readings collected. With a few exceptions which will be explained, the temperature distortion gradually increases from an average value of 0.5 percent tol percent. Temperature distortion percentage is computed from station 7 instrumentation; it is specifically computed as the maximum total temperature minus the minimum temperature divided by the computed average temperature. This computation was provided for each flow condition. Figure 10 shows a typical total temperature profile at maximum temperature and flow conditions. The exceptions on Fig. 9 show temperature distortions as high as 2.5 percent. These distortions were created by drastically reducing the weight flow of air while mapping operation conditions for Fig. 8. The mean temperature of the reduced air flow was heated by the hot walls of the HFJER, shown in the inverted temperature profile of Fig. 11. Before research data can be collected, a reasonable amount of time

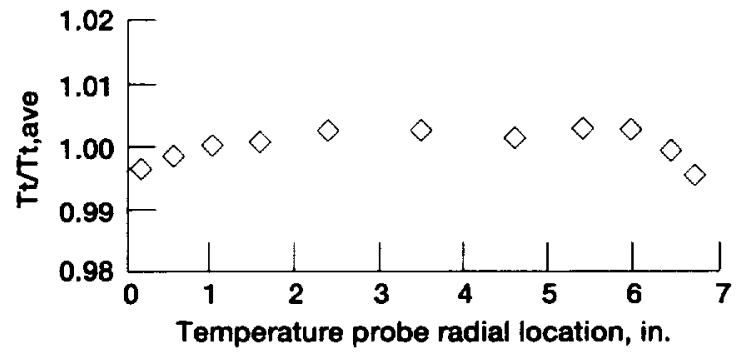

Figure 10.-Typical total temperature profile.

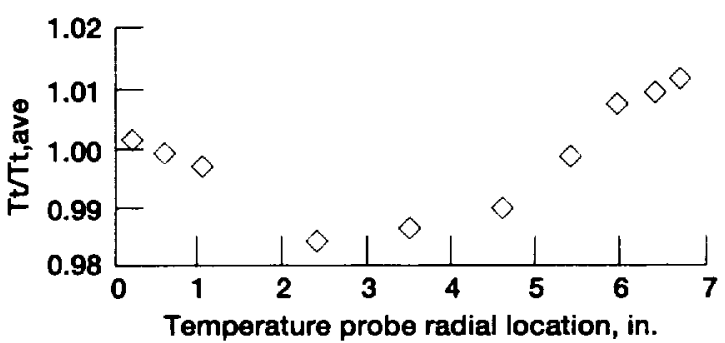

Figure 11.-Inverted total temperature profile.

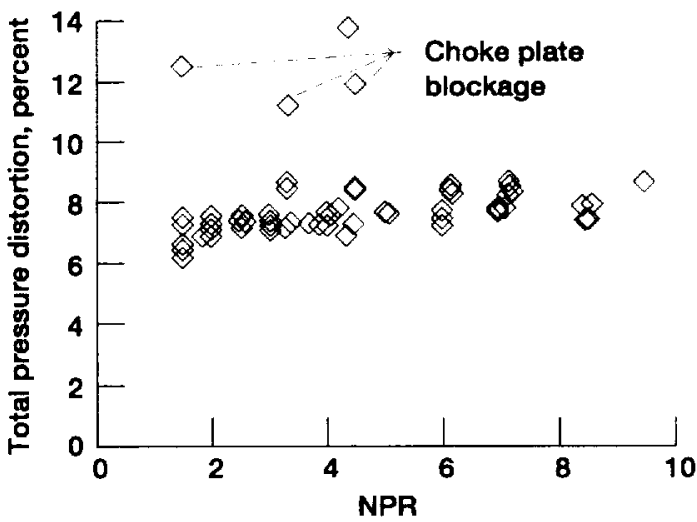

Figure 12.-HFJER total pressure distortion levels.

must be provided in future testing to allow the temperature profile to become stable after large changes in airflow or temperature are made.

Figure 12 shows the nozzle inlet pressure distortion for all readings collected. With a few exceptions which will be explained, the pressure distortion gradually increases from an average value of 7 percent at low flow to a value of 8 percent at high flow. Pressure distortion percentage is computed from station 7 instrumentation; and is specifically computed as the maximum total pressure minus the minimum pressure divided by the computed average pressure. This computation was provided for each flow condition. Figure 13 is a typical total pressure profile at cold flow conditions, and Fig. 14 is a typical total pressure profile at maximum temperature conditions. 


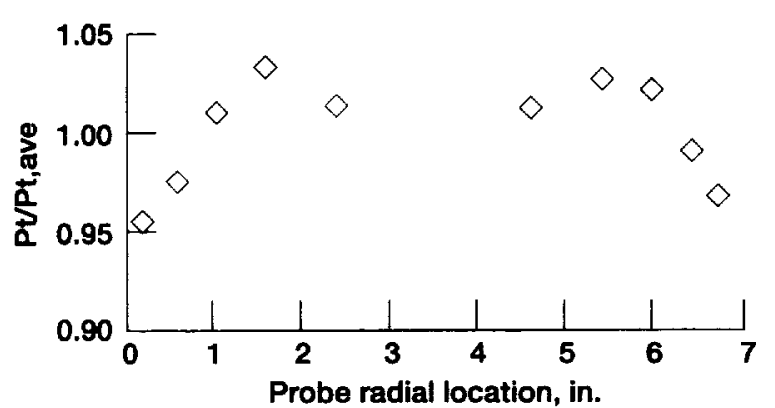

Figure 13.-Typical cold flow total pressure profile.

The results shown in Fig. 12 were collected over three test days on May 6, 8 and 9, 1997. A few results were also collected on May 19, 1997, which was the first test with the new aft support frame flexures. Four points on Fig. 12 show significantly high pressure distortions. These were caused by blockage in the choke plates which occurred during the May 19th test. A temperature related failure occurred in the lower manifold plenum downstream of the J-58 combustor. This failure melted parts of the internal insulated 4.5 in. diameter stainless steel flow sleeve, described previously. Fragments of the sleeve were carried up the strut and blocked airflow holes in the choke plates. The blocked holes caused the high levels of pressure distortion seen in Fig. 12. At this occurrence, testing was suspended until the problem could be identified and resolved. Repairs to the lower manifold plenum required two months. Schedule requirements did not permit the HFJER to remain in PSL-4 for the two additional months, terminating the checkout. The repair to the lower manifold tee is described in the HFJER mechanical description section of this report. The original design has been omitted. The failure of the combustor lower manifold tee restricted the collection of quality thrust coefficient results based on ASME nozzle testing with the new thrust balance

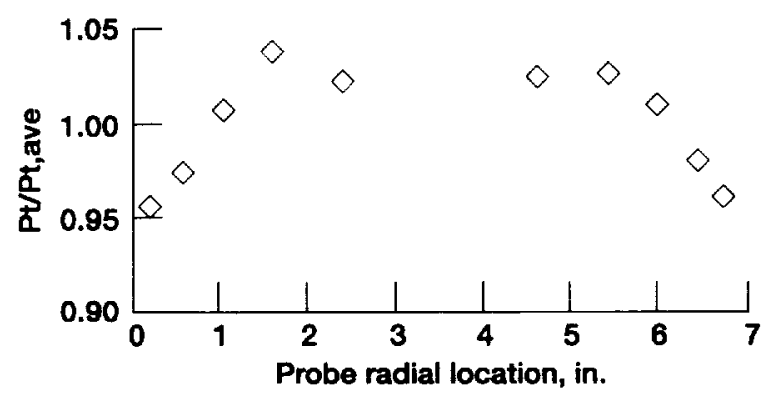

Figure 14.-Typical hot flow total pressure profile.

modifications. These important thrust measurement results will be collected and reported at a future date.

\section{Concluding Remarks}

The High Flow Jet Exit Rig (HFJER) was designed to simulate turbojet engine exhaust for $1 / 7$ scale High Speed Research nozzles. Checkout testing of this new rig confirmed the capabilities to deliver simulated engine exhaust to test nozzles with exhaust areas from 18 to 22 in. $^{2}$. Nozzles were tested at inlet pressures up to $57 \mathrm{psia}$; utilizing $33 \mathrm{lb}$ of air/sec cold flow and $20 \mathrm{lb}$ of air/ sec up to $1750^{\circ} \mathrm{R}$. Checkout testing also identified a problem with the single axis thrust measurement frame. The problem was identified and fixed during the checkout test period. Flow quality profiles of the air flow delivered to test nozzles were also examined. The test results are adequate to simulate the inlet conditions needed for NASA's High Speed Research nozzle testing program. Complete thrust calibration was not obtained due to a high temperature related failure of the lower air manifold assembly. Complete thrust calibration data will be collected and analyzed after a repair has been implemented. 



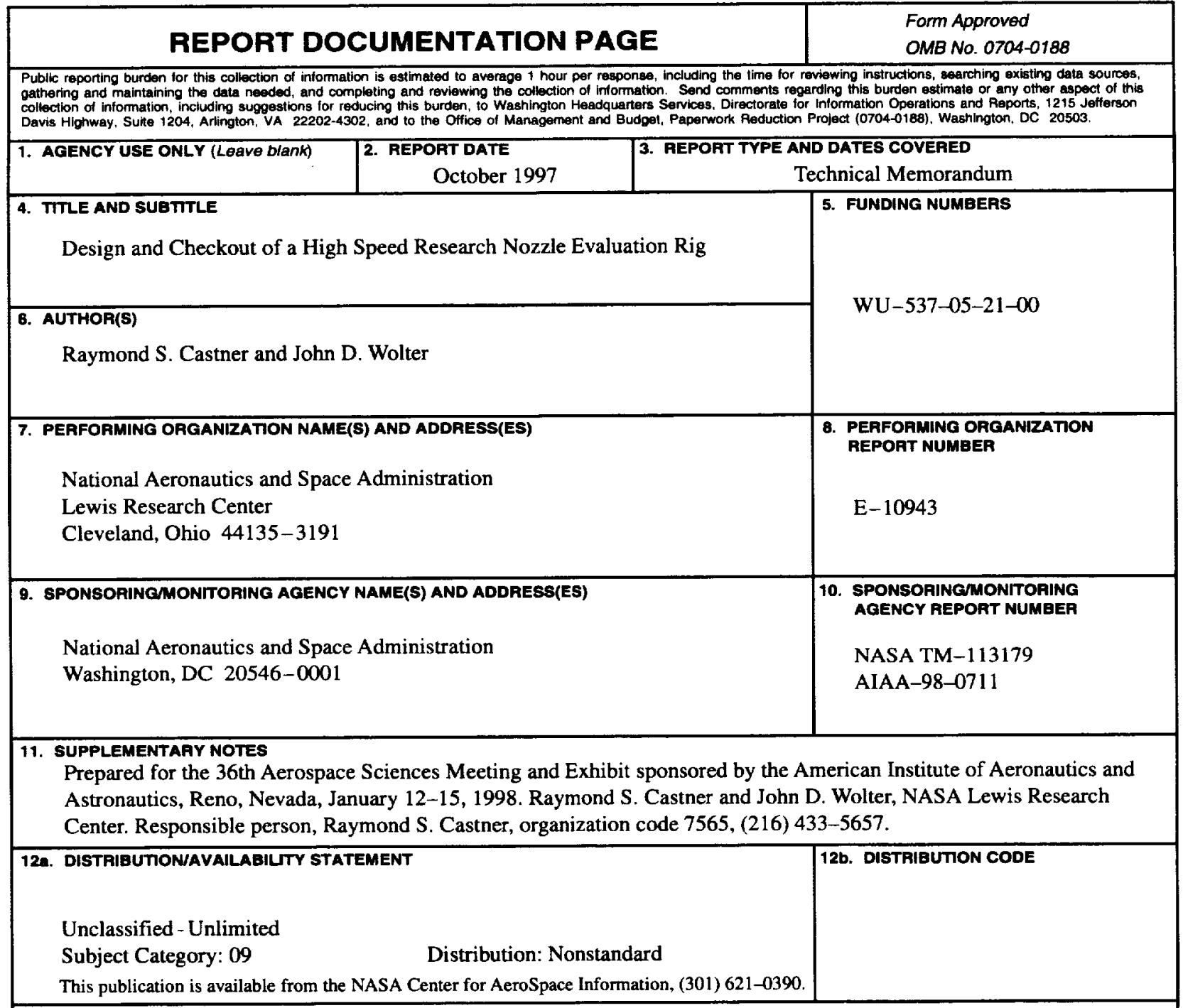

13. ABSTRACT (Maximum 200 words)

The High Flow Jet Exit Rig (HFJER) was designed to provide simulated mixed flow turbojet engine exhaust for oneseventh scale models of advanced High Speed Research test nozzles. The new rig was designed to be used at NASA Lewis Research Center in the Nozzle Acoustic Test Rig and the 8x6 Supersonic Wind Tunnel. Capabilities were also designed to collect nozzle thrust measurement, aerodynamic measurements, and acoustic measurements when installed at the Nozzle Acoustic Test Rig. Simulated engine exhaust can be supplied from a high pressure air source at 33 pounds of air per second at 530 degrees Rankine and nozzle pressure ratios of 4.0. In addition, a combustion unit was designed from a J-58 aircraft engine burner to provide 20 pounds of air per second at 2000 degrees Rankine, also at nozzle pressure ratios of 4.0. These airflow capacities were designed to test High Speed Research nozzles with exhaust areas from eighteen square inches to twenty-two square inches. Nozzle inlet flow measurement is available through pressure and temperature sensors installed in the rig. Research instrumentation on High Speed Research nozzles is available with a maximum of 200 individual pressure and 100 individual temperature measurements. Checkout testing was performed in May 1997 with a 22 square inch ASME long radius flow nozzle. Checkout test results will be summarized and compared to the stated design goals.

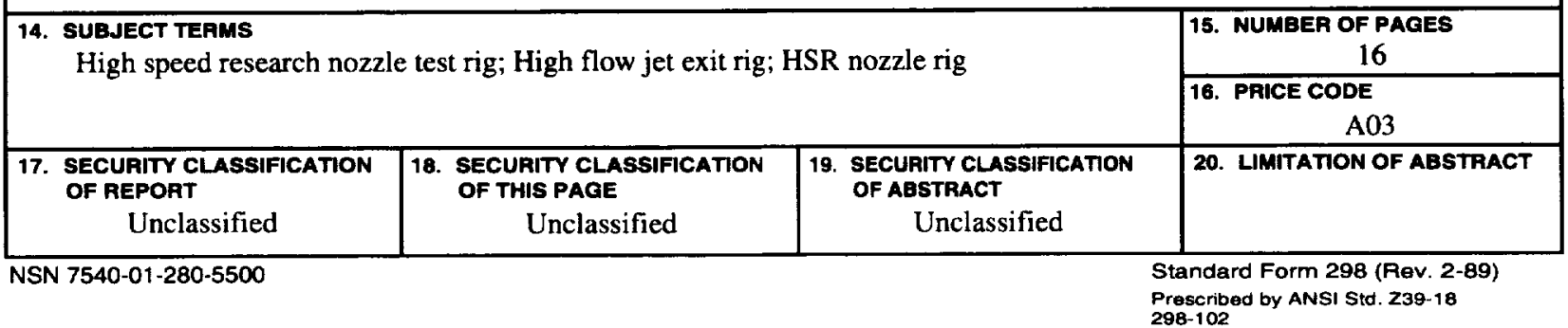

